\title{
Faktor-faktor yang berhubungan dengan tingkat kepuasan pasien rawat inap terhadap pelaksanaan konsultasi gizi ruangan di Rumah Sakit Umum Mataram
}

Siti Utami Sulasty ${ }^{1}$, R.Dwi Budiningsari², Setyowati ${ }^{3}$

\begin{abstract}
Background: Nutrition counseling is one of the nutrition services successful indicators in hospitals. The quality of nutrition counseling will improve the effectiveness and efficiency of resources utility and furthermore, it will improve patients' satisfaction. The quality of nutrition counseling services effect directly on internal and external customers' satisfaction. Evaluation about nutrition counseling services in hospital ward and its association with patients' satisfaction was needed to determine priority aspects to be improved.

Objective: To determine factors that associate with the rate of hospitalized patients' satisfaction towards nutrition counseling in Mataram Hospital.

Method: A total 38 hospitalized adult patients included in this observational study with cross sectional design. Proportional stratified sampling was conducted to determine subjects of study. Data collections included the description of nutrition counseling factors consisted of counselors, materials, methods, media, time, place, and visitation frequency of dietitians based on questionnaires completed directly by hospitalized adult patients. Spearman rank correlation and linear regression analysis were used to determine the association between nutrition counseling factors with the rate of hospitalized patients' satisfaction, completely by multiple linear regressions to analyze all of nutrition counseling factors in the same time.

Results: This study showed that counselors, time, place, and dietitians' nutrition counseling visitation were the significant factors associated with the rate of hospitalized adult patients' satisfaction $\left(R^{2}=0,086 p=0,027 ; R^{2}=0,099 p=0,017 ; R^{2}=\right.$ $0,108 p=0,013 ; R^{2}=0,166 p=0,002$, respectively). The most dominant factors among all of associated factors were visitation frequency of dietitians $(p=0,035)$.

Conclusion: There was a significant association between counselors, time, place, and dietitians' nutrition counseling visitation frequency with the rate of hospitalized patients' satisfaction. The most dominant factors among all of associated factors were visitation frequency of dietitians.
\end{abstract}

KEY WORDS the rate of patients' satisfaction, nutrition counseling factors

\section{PENDAHULUAN}

Intervensi gizi merupakan salah satu langkah dalam pelaksanaan terapi gizi medis yang merupakan tujuan pokok dari rancangan kegiatan dalam terapi gizi medis. Kegiatan ini dimaksudkan agar terjadi perubahan perilaku yang berkaitan dengan gizi, faktor risiko, kondisi lingkungan, atau aspek kesehatan individu. Intervensi gizi menurut Departemen Kesehatan R.I. dapat berupa penyelenggaraan makanan dan konseling gizi (1).

Setiap pasien berhak mendapat konsultasi gizi yang berkualitas karena konsultasi gizi merupakan bagian integral yang strategis dalam mempercepat proses penyembuhan pasien. Selain itu, konsultasi gizi yang berkualitas juga dapat meningkatkan efektivitas serta efisiensi penggunaaan sumber daya dan memberikan kepuasan kepada pasien. Pasien di rumah sakit memiliki kebutuhan, pilihan, kepentingan, keunikan dan sensitivitas yang berbeda, sehingga konsultasi gizi di rumah sakit sebaiknya disesuaikan dengan kebutuhan, kepentingan, dan harapan pasien (2).

Faktor-faktor yang dapat mempengaruhi tingkat kepuasan pasien terhadap konsultasi gizi berkaitan dengan karakteristik pasien, antara lain: umur, pendidikan, jenis kelamin, dan lain- lain. Sementara itu, aspek-aspek yang diperlukan dalam pelaksanaan konsultasi gizi yaitu pola pelaksanaan kegiatan konsultasi gizi yang terdiri dari: cara pendekatan, metode, materi, media, tempat, dan waktu (3).

Salah satu indikator yang dapat digunakan untuk menilai atau mengukur kualitas konsultasi gizi adalah indikator yang tidak diharapkan. Indikator tersebut menilai suatu kondisi yang kadang-kadang tidak diharapkan, seperti keluhan pasien terhadap pelayanan konsultasi diet (2).

Rumah Sakit Umum (RSU) Mataram merupakan rumah sakit milik pemerintah Provinsi Nusa Tenggara Barat dengan tipe B pendidikan. Berdasarkan laporan penyelenggaraan pelayanan gizi di RSU Mataram, rata-rata pasien rawat inap yang mendapat konsultasi gizi pada tahun 2006 sebanyak 210 orang/bulan, sedangkan BOR (bed occupancy rate)

\footnotetext{
Rumah Sakit Umum Mataram, Jl. Pejanggik No. 6 Mataram, e-mail: amik_lombok@yahoo.com

2 Magister Gizi dan Kesehatan UGM, JI. Farmako, Sekip Utara, Yogyakarta 55281, e-mail: budiningsari25@yahoo.com

3 Politeknik Kesehatan Departemen Kesehatan R.I., Jl. Tatabumi No. 3, Yogyakarta
} 
sebesar $89 \%$ dengan jumlah rata-rata pasien per hari 239 pasien rawat inap. Instalasi gizi RSU Mataram telah melaksanakan pelayanan konsultasi gizi, baik secara perorangan maupun kelompok. Konsultasi gizi ruangan telah dilakukan di semua kelas perawatan inap yang ada, baik di kelas VIP, kelas I, II dan III. Konselor terdiri dari ahli gizi Iulusan D3 dan D4 jurusan gizi yang menangani 1 hingga 2 kelas perawatan inap. Selama ini, belum pernah dilakukan evaluasi tentang pelayanan konsultasi gizi di kelas perawatan inap dilihat dari segi kepuasan pasien. Selain itu, belum diketahui juga aspek-aspek dalam pelaksanaan konsultasi gizi yang masih perlu diperbaiki sebagai prioritas utama, baik itu yang mencakup konselor, materi, metode, media, waktu, tempat, dan frekuensi kunjungan ahli gizi.

Oleh karena itu, perlu dilakukan penelitian mengenai faktor-faktor yang berhubungan dengan kepuasan pasien rawat inap terhadap pelaksanaan konsultasi gizi di ruang rawat inap RSU Mataram.

\section{BAHAN DAN METODE}

Penelitian ini adalah penelitian observasional dengan rancangan penelitian cross sectional. Penelitian dilakukan di ruang rawat inap Rumah Sakit Umum (RSU) Mataram selama bulan Juli-November 2008.

Responden penelitian ditentukan dengan kriteria inklusi, yaitu: pasien yang dirawat di kelas I, II dan III; berusia $\geq 19$ tahun; dalam keadaan sadar dan dapat berkomunikasi dengan baik; dan minimal telah dirawat selama 3 hari. Sementara itu, kriteria eksklusi meliputi: pasien yang tidak dapat membaca serta kuesioner tidak diisi dengan lengkap. Besar sampel minimal yang dihitung sebesar 38 orang dengan menggunakan rumus besar sampel untuk survei sampel dengan pendugaan $P$ dalam jarak "d" persen dengan kekuatan $95 \%$, nilai koefisien keterandalan $Z^{2}{ }_{1-\alpha / 2}$ adalah 1,96, dan tingkat presisi $10 \%$ (4). Pengambilan sampel dilakukan dengan metode proportional stratified sampling berdasarkan rata-rata jumlah pasien kelas perawatan I, II, dan III yang mendapatkan konsultasi gizi dikalikan dengan besar sampel, sehingga besar sampel untuk masing-masing kelas I, II, dan III berturut-turut sebanyak 4, 12, dan 22 pasien.

Data yang dikumpulkan pada penelitian ini adalah semua pelayanan konsultasi di RSU Mataram yang mencakup: konselor, materi, metode, media, waktu, tempat, dan frekuensi kunjungan ahli gizi.

Konselor merupakan petugas konsultasi gizi dengan pendidikan minimal D3. Penilaian konselor didasarkan pada waktu kedatangan, penampilan, sikap, keterampilan dalam penguasaan materi, berkomunikasi, motivasi, dan perhatian terhadap keluhan pasien. Data dikumpulkan dengan kuesioner $B$ yang terdiri dari 8 pertanyaan pada rentang skor 3-1 (skor maksimum 24).

Materi konsultasi disesuaikan dengan jenis penyakit dan kebutuhan pasien. Data dikumpulkan dengan menggunakan kuesioner $\mathrm{C}$ dengan dasar penilaian isi dan kesesuaian materi. Kuesioner $\mathrm{C}$ terdiri dari 4 pertanyaan dengan skor 3-1 (nilai maksimum 12).

Metode konsultasi merupakan cara yang digunakan konselor dalam menyampaikan materi konsultasi gizi kepada pasien dengan dasar penilaian variasi metode yang digunakan dan dukungannya terhadap pemahaman materi. Penilaian terhadap metode konsultasi diterjemahkan dalam kuesioner $\mathrm{D}$ yang terdiri dari 3 pertanyaan dengan skor 3-1 (nilai maksimum 9).

Media konsultasi merupakan alat bantu berupa leaflet tata cara pelaksanaan diet dan daftar bahan makanan penukar yang digunakan oleh konselor dalam menyampaikan materi konsultasi. Penilaian media konsultasi didasarkan pada isi dan bentuk leaflet yang diungkapkan dengan menggunakan kuesioner $E$ yang berisi 3 pertanyaan (rentang skor 3-1 dan nilai maksimum 9).

Waktu konsultasi merupakan lamanya konselor dalam menyampaikan materi kepada pasien. Penilaian waktu konsultasi didasarkan atas lamanya konsultasi yang diberikan pada konsultasi pertama dan diungkapkan dengan kuesioner F yang terdiri dari jawaban cukup dan kurang.

Tempat konsultasi adalah ruang rawat inap menurut kelas perawatan yang digunakan sebagai tempat konselor dalam memberikan konsultasi. Tempat konsultasi dinilai berdasarkan kenyamanan, pencahayaan, sirkulasi udara, dan kebersihan dengan menggunakan kuesioner $\mathrm{G}$ yang berisi 4 pertanyaan. Rentang skor ditentukan 3-1 dengan nilai maksimum yang diharapkan adalah 12.

Frekuensi kunjungan ahli gizi adalah jumlah kunjungan yang dilakukan konselor sejak pertama pasien masuk rumah sakit hingga saat dilakukan penelitian dan diungkapkan dengan kuesioner $\mathrm{H}$ yang terdiri dari jawaban cukup dan kurang.

Tingkat kepuasan pasien rawat inap adalah jumlah skor yang diperoleh dari 25 pernyataan yang diisi oleh pasien melalui kuesioner I. Jawaban menggunakan skala Likert dengan 1 yang merupakan nilai terendah dan 4 untuk nilai tertinggi. Kategori jawaban untuk pernyataan positif dimulai dari sangat tidak setuju (STS), tidak setuju (TS), setuju (S), dan sangat setuju (SS). Adapun nilai maksimum yang diharapkan adalah 100.

Data yang telah terkumpul kemudian diolah dengan cara editing dan coding secara manual, kemudian ditabulasi dari skor jawaban yang diperoleh dengan menggunakan tabel penyajian hasil pengolahan data guna menyusun uraian-uraian yang dilengkapi dengan penjelasan serta penyajian dalam bentuk diagram maupun tabel. Selanjutnya, data dianalisis menggunakan uji linear regression dan Spearman rank correlation. Uji korelasi dan regresi linear digunakan untuk melihat hubungan antara variabel, sedangkan uji linear berganda digunakan untuk melihat variabel yang paling berpengaruh terhadap variabel independen. 


\section{HASIL DAN BAHASAN}

\section{Karakteristik responden}

Pasien rawat inap yang memenuhi kriteria inklusi dan eksklusi selama penelitian sebanyak 57 responden, 7 orang $(12,3 \%)$ berasal dari kelas I, 18 orang $(31,6 \%)$ orang kelas II, dan 32 orang $(56,1 \%)$ kelas III. Karakteristik responden pada saat penelitian dapat dilihat pada Tabel 1. Dari tabel tersebut dapat diketahui bahwa pasien rawat inap yang mendapat konsultasi gizi ruangan dan menjadi responden adalah dominan pasien berusia dewasa, laki-laki, berpendidikan SMA (sekolah menengah atas), memiliki pekerjaan sebagai wiraswasta, dirawat di ruang kelas III, bersuku Sasak, dengan diagnosis diabetes mellitus (DM), mendapat konsultasi mengenai DM $1.900 \mathrm{kkal}$, mendapat kunjungan konsultasi pertama pada hari kedua masuk sebagai pasien rawat inap, dan merupakan pasien yang baru pertama kali menjadi pasien rawat inap di RSU Mataram.

\section{Penilaian responden terhadap pelayanan konsultasi gizi ruangan}

Pada penelitian ini, penilaian responden terhadap pelaksanaan konsultasi gizi ruangan berdasarkan 25 butir pernyataan menggunakan kuesioner yang langsung diisi sendiri oleh responden. Jawaban setiap responden dijumlahkan, kemudian dikelompokkan berdasarkan jumlah skor yang diperoleh. Skor tertinggi yang diharapkan adalah 100 , sedangkan yang terendah adalah 25 . Skor 72 merupakan skor terbanyak yang dimiliki responden terhadap pernyataan kepuasan pelaksanaan konsultasi gizi, yaitu sebanyak 11 orang (19,3\%). Distribusi responden berdasarkan jumlah skor pernyataan kepuasan terhadap pelaksanaan konsultasi gizi ditampilkan pada Tabel 2.

\section{Hubungan antara konselor dengan tingkat kepuasan pasien}

Hasil analisis Spearman rank correlation untuk menguji hubungan antara konselor dengan tingkat kepuasan pasien menunjukkan tidak ada hubungan antara kedua variabel $(p=$ $0,143$ dan $r=0,196)$. Walaupun tidak terdapat hubungan antara konselor gizi dengan tingkat kepuasan pasien, dari Gambar 1 diketahui bahwa $100,0 \%$ responden menilai konselor rapi, ramah, memperhatikan keluhan dengan baik, dan selalu memberi motivasi yang mendukung tercapainya tujuan pelaksanaan diet. Selain itu, 93,0\% responden menilai konselor menyampaikan tujuan konsultasi dengan jelas, 94,7\% menilai konselor menguasai materi konsultasi dengan baik, 89,5\% responden menilai bahasa yang digunakan konselor mudah dipahami walaupun masih terdapat $10,5 \%$ yang menilai bahasa yang digunakan konselor kurang dapat dipahami. Hal ini dapat disebabkan adanya perbedaan suku antara responden dengan konselor. Pada penelitian ini, sebagian besar responden $(68,4 \%)$ bersuku Sasak, sedangkan konselor bersuku Sasak, Jawa, dan Bima.
Sebanyak $84,2 \%$ responden menilai penjelasan yang diberikan konselor mudah dimengerti, tetapi masih terdapat $15,8 \%$ responden yang menilai penjelasan konselor kurang dapat dimengerti karena tingkat pendidikan responden beragam. Hal ini sesuai dengan penelitian yang dilakukan oleh Umarella (5), Asih (6) dan Lamri (7) yang menyatakan bahwa tingkat pendidikan berhubungan dengan tingkat kepuasan pasien. Hal ini juga berkaitan erat dengan keahlian dan keterampilan konselor untuk membantu klien, serta sikap yang dimiliki untuk menjalani hubungan konseling (8).

Pasien sangat membutuhkan keramahan dalam setiap pelayanan yang diterima termasuk pelayanan konsultasi gizi yang dilakukan konselor. Pendapat senada dikemukakan oleh Gazperz dalam Fandani (9) yang menyatakan bahwa pelayanan seharusnya bersikap sopan dan ramah tamah terhadap konsumen.

\section{Hubungan antara materi konsultasi dengan tingkat kepuasan pasien}

Materi konsultasi yang diberikan oleh konselor disesuaikan dengan diagnosis penyakit dan kemampuan pasien. Dari hasil uji korelasi antara konsultasi dengan tingkat kepuasan pasien diketahui nilai $p=0,143$ dan $r=0,197$ yang menunjukkan tidak ada hubungan antara kedua variabel tersebut.

Dari Gambar 2 diketahui bahwa 84,2\% responden menilai materi yang diberikan sesuai dengan kebutuhan dan penjelasan mengenai bahan makanan penukar dapat dipahami dengan baik, 78,9\% responden menilai isi materi yang diberikan jelas, dan $68,4 \%$ menilai urutan penyampaian materi berurutan. Walaupun demikian, terdapat $1,8 \%$ responden yang berpendapat penyampaian materi tidak berurutan.

Materi konsultasi yang diberikan di ruang rawat inap RSU Mataram diberikan sesuai dengan diagnosis pasien dan keadaan pasien. Materi konsultasi yang diberikan tersebut belum tersusun dalam sebuah SOP (standard operating procedure), sehingga penyampaian konsultasi antara satu konselor dengan konselor lain relatif berbeda. Hal ini merupakan salah satu hal yang dapat menjelaskan masih terdapatnya pasien yang menilai materi konsultasi yang diberikan kurang sesuai kebutuhan (15,8\%), isi materi kurang jelas $(21,1 \%)$, penyampaian materi kurang berurutan $(29,8 \%)$ dan penjelasan mengenai bahan makanan kurang dapat dipahami (15,8\%). Materi konsultasi yang sesuai dengan kebutuhan pasien serta dapat dipahami, dimengerti, dan disukai menjadikan konsultasi gizi lebih efektif $(10,11)$. Menurut Curry dan Jaffe (12), materi yang diberikan pada pasien tertentu belum tentu cocok untuk pasien yang lain.

\section{Hubungan antara metode konsultasi dengan tingkat kepuasan pasien}

Hasil uji korelasi antara metode konsultasi dengan tingkat kepuasan pasien menggunakan Spearman rank correlation menunjukkan nilai $p=0,796$ dan $r=0,035$. Hasil ini 
TABEL 1. Karakteristik responden penelitian

\begin{tabular}{|c|c|c|}
\hline Karakter & Jumlah & Persentase (\%) \\
\hline \multicolumn{3}{|l|}{ Jenis kelamin } \\
\hline Laki-laki & 30 & 52,6 \\
\hline Perempuan & 27 & 47,4 \\
\hline \multicolumn{3}{|l|}{ Umur } \\
\hline Dewasa (19-60 tahun) & 49 & 86,0 \\
\hline Usia lanjut ( $\geq 60$ tahun) & 8 & 14,0 \\
\hline \multicolumn{3}{|l|}{ Tingkat pendidikan } \\
\hline Sekolah dasar (SD) & 15 & 26,3 \\
\hline Sekolah menengah pertama (SMP) & 14 & 24,6 \\
\hline Sekolah menengah atas (SMA) & 25 & 43,8 \\
\hline Sarjana & 3 & 5,3 \\
\hline \multicolumn{3}{|l|}{ Pekerjaan } \\
\hline PNS/ABRI/POLRI & 7 & 12,3 \\
\hline Pegawai swasta & 1 & 1,8 \\
\hline Wiraswasta & 28 & 49,1 \\
\hline Pensiunan & 3 & 5,3 \\
\hline Lain-lain & 6 & 10,5 \\
\hline Tidak bekerja & 12 & 21,0 \\
\hline \multicolumn{3}{|l|}{ Kelas perawatan } \\
\hline Kelas I & 7 & 12,3 \\
\hline Kelas II & 18 & 31,6 \\
\hline Kelas III & 32 & 56,1 \\
\hline \multicolumn{3}{|l|}{ Daerah asal/suku } \\
\hline Sasak & 39 & 68,3 \\
\hline Bima & 2 & 3,5 \\
\hline Sumbawa & 7 & 12,3 \\
\hline Dompu & 1 & 1,8 \\
\hline Bali & 7 & 12,3 \\
\hline Jawa & 1 & 1,8 \\
\hline \multicolumn{3}{|l|}{ Diagnosis penyakit } \\
\hline Diabetes mellitus & 23 & 40,4 \\
\hline Jantung dan pembuluh darah & 18 & 31,5 \\
\hline Ginjal dan saluran kencing & 10 & 17,4 \\
\hline Anemia & 3 & 5,3 \\
\hline Saluran cerna & 1 & 1,8 \\
\hline Komplikasi kehamilan & 1 & 1,8 \\
\hline Tumor & 1 & 1,8 \\
\hline \multicolumn{3}{|l|}{ Pertama kali mendapat konsultasi pertama } \\
\hline Hari pertama & 12 & 21,1 \\
\hline Hari kedua & 21 & 36,8 \\
\hline Hari kedua & 14 & 24,6 \\
\hline Hari keempat & 6 & 10,5 \\
\hline Hari kelima & 2 & 3,5 \\
\hline Hari keenam & 2 & 3,5 \\
\hline \multicolumn{3}{|l|}{ Materi konsultasi } \\
\hline Diabetes mellitus 1.900 kkal & 23 & 38,6 \\
\hline Rendah protein rendah garam rendah kalium & 8 & 14,1 \\
\hline Rendah garam & 5 & 8,8 \\
\hline Rendah garam rendah lemak & 5 & 8,8 \\
\hline Tinggi kalori tinggi protein & 5 & 8,8 \\
\hline Diet jantung & 3 & 5,3 \\
\hline Diet jantung rendah garam & 3 & 5,3 \\
\hline Tinggi kalori tinggi protein rendah garam & 2 & 3,5 \\
\hline Diet lambung & 1 & 1,8 \\
\hline Rendah kolesterol & 1 & 1,8 \\
\hline Rendah kalsium & 1 & 1,8 \\
\hline \multicolumn{3}{|l|}{ Jumlah kunjungan rawat inap } \\
\hline 1 kali & 47 & 82,4 \\
\hline 2 kali & 7 & 12,3 \\
\hline 3 kali & 3 & 5,3 \\
\hline
\end{tabular}


TABEL 2. Distribusi responden berdasarkan kepuasan pelaksanaan konsultasi gizi

\begin{tabular}{ccc}
\hline $\begin{array}{c}\text { Nilai } \\
\text { responden }\end{array}$ & Jumlah & $\begin{array}{c}\text { Persentase } \\
(\%)\end{array}$ \\
\hline 96 & 3 & 5,3 \\
90 & 2 & 3,5 \\
80 & 1 & 1,8 \\
79 & 1 & 1,8 \\
78 & 6 & 10,5 \\
77 & 3 & 5,3 \\
76 & 1 & 1,8 \\
75 & 3 & 5,3 \\
74 & 4 & 7,0 \\
73 & 2 & 3,5 \\
72 & 11 & 19,3 \\
71 & 3 & 5,3 \\
70 & 4 & 7,0 \\
69 & 4 & 7,0 \\
68 & 3 & 5,3 \\
67 & 3 & 5,3 \\
62 & 1 & 1,8 \\
61 & 1 & 1,8 \\
59 & 1 & 1,8 \\
Jumlah & $\mathbf{5 7}$ & $\mathbf{1 0 0 , 0}$ \\
\hline
\end{tabular}

dan tanyajawab. Selain itu, $63,2 \%$ responden juga menilai metode yang digunakan bervariasi dan $89,5 \%$ menilai metode yang digunakan membantu responden dalam memahami materi yang diberikan konselor. Ngadiarti (13) menyatakan bahwa pasien akan mengeluh jika konsultasi diberikan dengan metode yang monoton. Mengeluh merupakan salah satu indikator ketidakpuasan pasien.

\section{Hubungan antara media konsultasi dengan tingkat kepuasan pasien}

Hasil perhitungan korelasi antara media konsultasi dengan tingkat kepuasan pasien didapatkan nilai r sebesar 0,193 dan $p$ sebesar 0,151 . Dengan demikian, tidak ada hubungan antara media konsultasi dengan tingkat kepuasan pasien terhadap pelaksanaan konsultasi gizi ruangan di RSU Mataram.

Media yang digunakan dalam penelitian ini adalah leaflet. Gambar 4 menunjukkan bahwa $91,2 \%$ responden menilai bentuk leaflet menarik, bahkan $75,4 \%$ responden di antaranya menilai isi leaflet diet dan bahan makanan penukar mudah dimengerti. Walaupun demikian, terdapat $1,8 \%$ responden yang menilai isi kedua leaflet tersebut sulit dimengerti.

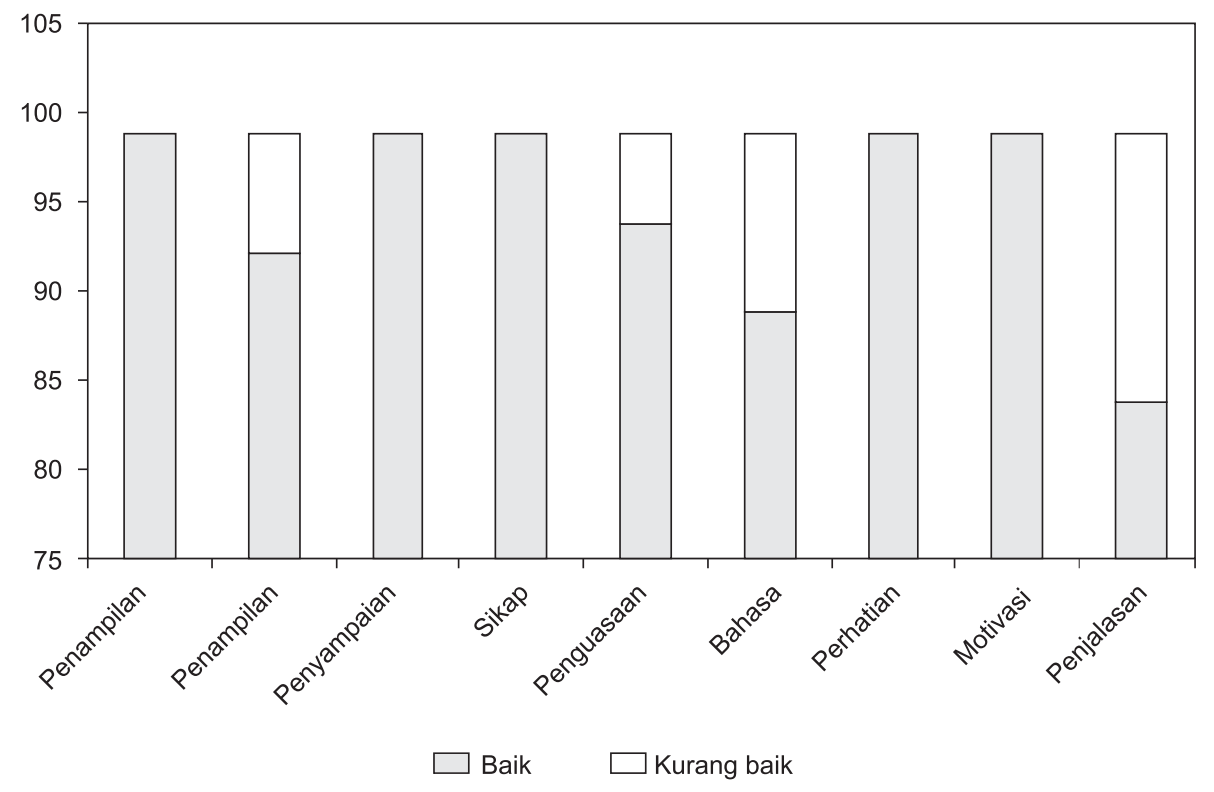

GAMBAR 1. Penilaian responden terhadap konselor

membuktikan bahwa tidak ada hubungan antara metode konsultasi dengan tingkat kepuasan pasien rawat inap terhadap pelaksanaan konsultasi gizi ruangan di RSU Mataram.

Berdasarkan Gambar 3 diketahui bahwa dari 57 responden, $57,9 \%$ di antaranya menilai konselor menggunakan 2 metode penyampaian konsultasi, namun tidak ada responden yang menyatakan mendapat 3 metode penyampaian konsultasi. Dua metode konsultasi yang dimaksud pada penelitian ini meliputi: wawancara dan ceramah, wawancara dan tanya jawab, ceramah dan tanya jawab, atau ceramah dan tanya jawab; sedangkan 3 metode konsultasi yang dimaksud meliputi: wawancara, ceramah,
Media dibutuhkan untuk meningkatkan pemahaman konsultasi gizi yang diberikan dan mengingat materi yang disampaikan. Setiap alat peraga mempunyai daya serap yang berbeda sehingga penggunaan alat bantu lebih dari satu sangat dianjurkan (10). Selain leaflet, media yang tersedia di Instalasi Gizi RSU Mataram adalah food models. Jumlah food models yang terbatas menyebabkan media ini hanya digunakan untuk konsultasi rawat jalan dan kegiatan penyuluhan kelompok. Makanan pasien juga dapat digunakan sebagai alat bantu konsultasi, namun hanya dapat dilakukan pada sebagian pasien. Hal ini disebabkan pada saat 


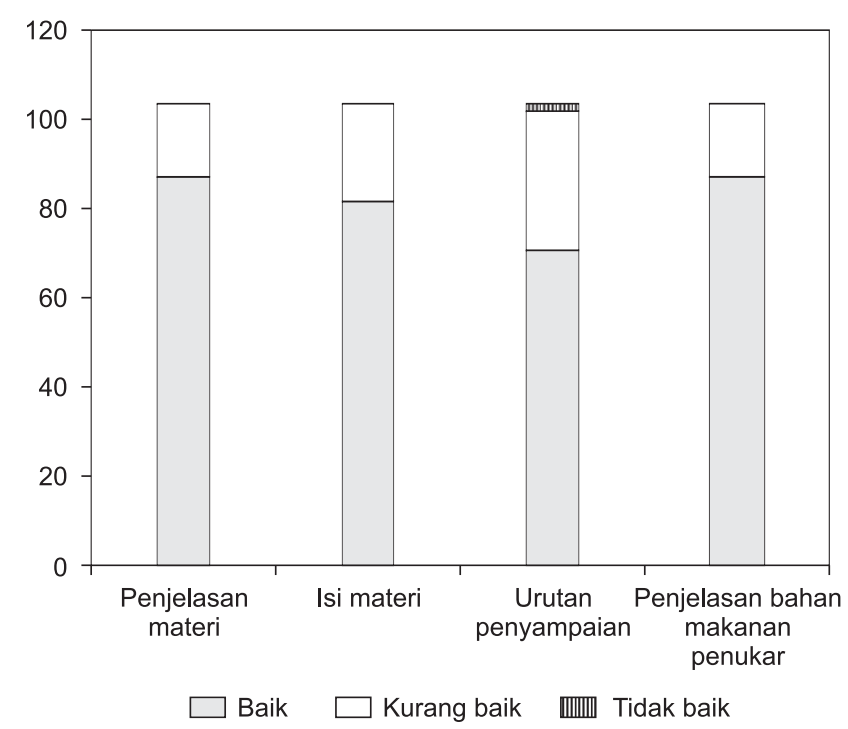

GAMBAR 2. Penilaian responden terhadap materi konsultasi

melakukan konsultasi gizi ruangan, pasien telah selesai makan atau makanan belum sampai kepada pasien, sehingga alat peraga yang selalu digunakan adalah hanya leaflet diit dan leaflet bahan makanan penukar.

\section{Hubungan antara waktu konsultasi dengan tingkat kepuasan pasien}

Waktu konsultasi untuk pasien rawat inap yang baik disesuaikan dengan keadaan dan kesediaan pasien (1). Waktu konsultasi yang baik menurut Departemen Kesehatan dan Kesejahteraan Sosial R.I. (10) berkisar antara 30 -60 menit, sedangkan berdasarkan penelitian yang dilakukan Iswidani (14) diketahui bahwa waktu yang efektif untuk konsultasi pada pasien DM (diabetes mellitus) di poliklinik gizi adalah 15-30 menit. Konsultasi gizi di RSU Mataram berkisar antara 5-20 menit (Tabel 3). Dari hasil uji Spearman rank correlation diketahui ada hubungan yang bermakna antara waktu konsultasi gizi dengan tingkat kepuasan pasien terhadap pelaksanaan konsultasi gizi ruangan. Nilai koefisien korelasi menunjukkan hasil yang positif dengan keeratan sedang ( $p=0,000$ dan $r=0,452)$. Hal ini sesuai dengan persyaratan penyelenggaraan konsultasi yang baik, yaitu dengan waktu yang cukup pasien dapat merasa puas dengan pelaksanaan konsultasi gizi (1).

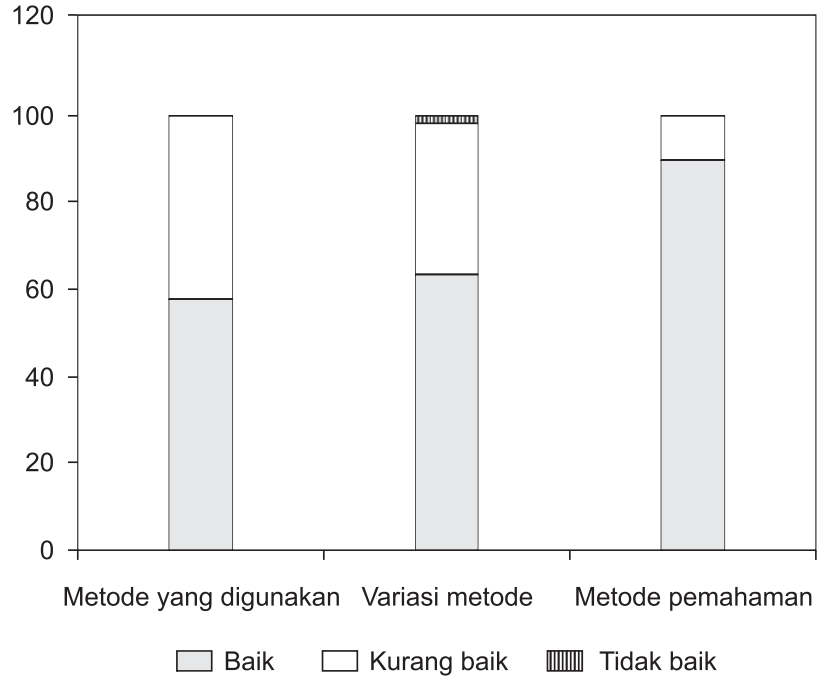

GAMBAR 3. Penilaian responden terhadap metode konsultasi

Waktu yang cukup antara satu pasien dengan pasien lainnya tidak sama. Hal ini dapat disebabkan oleh keadaan masing-masing pasien yang dapat dilihat pada Tabel 2. Dari $61,4 \%$ responden yang mendapatkan konsultasi selama 10 menit, $47,3 \%$ di antaranya menilai konsultasi selama waktu tersebut telah cukup; sedangkan dari $26,3 \%$ responden yang mendapat konsultasi selama 5 menit, $15,8 \%$ di antaranya merasa cukup selama waktu tersebut. Hal ini dapat disebabkan $56,1 \%$ responden adalah pasien kelas III yang tidak memiliki sekat pembatas yang dapat menjaga privacy. Menurut Gable (15), cara untuk membina lingkungan yang kondusif antara konselor dengan pasien adalah menjaga privacy pasien.

\section{Hubungan antara tempat dengan tingkat kepuasan pasien}

Ruang konsultasi gizi pasien rawat inap adalah ruang rawat masing-masing pasien. Ruang kelas I menampung 2 orang pasien dengan kamar mandi di dalam dan fasilitas AC (air conditioner), tempat tidur pasien dipisah menggunakan tirai, sehingga privacy pasien dapat terpenuhi. Ruang kelas II menampung 4 orang pasien dengan kamar mandi di dalam untuk kelas IIAdan kamar mandi di luar untuk kelas II B, tempat tidur pasien dipisah menggunakan tirai. Adapun ruang kelas III menampung 6 pasien dengan kamar mandi di luar dan tempat tidur pasien tidak dipisah dengan tirai,

TABEL 3. Distribusi responden berdasarkan waktu konsultasi

\begin{tabular}{lcccccc}
\hline Waktu & \multicolumn{2}{c}{ Cukup } & \multicolumn{2}{c}{ Kurang } & \multicolumn{2}{c}{ Jumlah } \\
\cline { 2 - 7 } konsultasi & $\mathbf{n}$ & $\mathbf{\%}$ & $\mathbf{n}$ & $\mathbf{\%}$ & $\mathbf{n}$ & $\mathbf{\%}$ \\
\hline 5 menit & 9 & 15,8 & 6 & 10,5 & 15 & 26,3 \\
10 menit & 27 & 47,3 & 8 & 14,1 & 35 & 61,4 \\
15 menit & 5 & 8,8 & 0 & 0 & 5 & 8,8 \\
20 menit & 2 & 3,5 & 0 & 0 & 2 & 3,5 \\
Jumlah & $\mathbf{4 3}$ & $\mathbf{7 5 , 4}$ & $\mathbf{1 4}$ & $\mathbf{2 4 , 6}$ & $\mathbf{5 7}$ & $\mathbf{1 0 0}$ \\
\hline
\end{tabular}




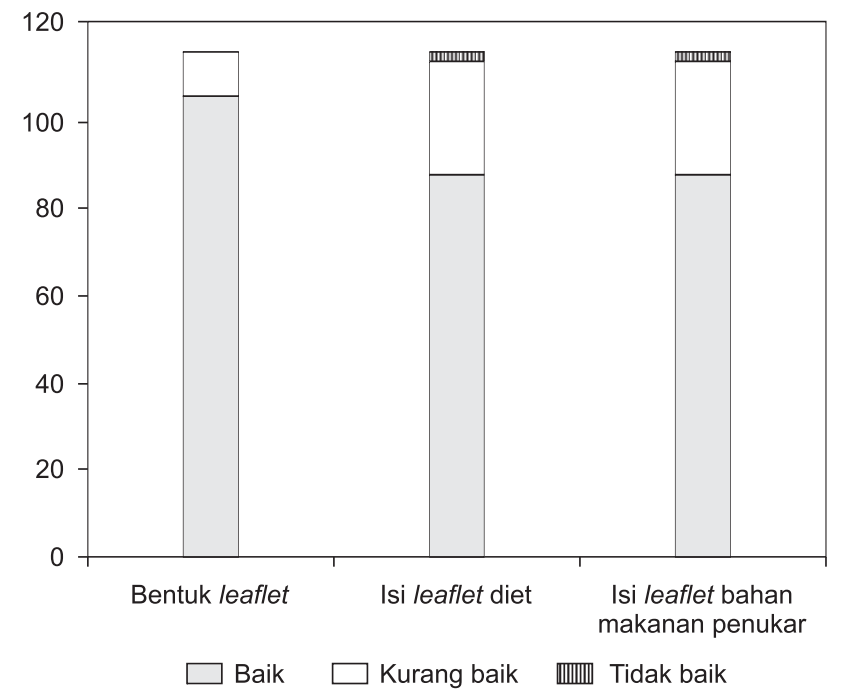

GAMBAR 4. Penilaian responden terhadap media konsultasi

sehingga privacy pasien tidak diperoleh. Setelah dilakukan uji korelasi, diketahui bahwa nilai $p=0,002$ dan nilai $r=0,403$ yang menunjukkan ada hubungan antara tempat konsultasi dengan tingkat kepuasan pasien rawat inap terhadap pelaksanaan konsultasi gizi ruangan di RSU Mataram.

Mutu pelayanan tergantung pada penampilan, baik tempat pelayanan maupun fasilitas fisik yang dimiliki (9). Ruangan rawat inap sebagai tempat dilaksanakannya konsultasi gizi ruangan terdiri dari kelas I, kelas II, dan kelas III. Berdasarkan Gambar 5 diketahui bahwa dari 57 responden, $77,2 \%$ responden di antaranya menyatakan ruangan nyaman dan $3,5 \%$ menyatakan tidak nyaman, $64,9 \%$ responden menilai ruangan terang dan $3,5 \%$ menilai ruangan tidak terang, $52,6 \%$ responden menilai ruangan bersih dan $7,0 \%$ menilai tidak bersih, selanjutnya $57,9 \%$ menilai sirkulasi ruangan baik dan 5,3\% menilai sirkulasi udara tidak baik. Hal ini sesuai dengan indikator yang disusun Suryawati (16) yaitu kondisi fisik ruangan mempengaruhi tingkat kepuasan pasien. Makin baik kondisi fisik ruangan, makin meningkat kepuasan pasien.

\section{Hubungan antara frekuensi konsultasi dengan tingkat kepuasan pasien}

Kunjungan konselor untuk memberikan konsultasi gizi di ruang rawat inap RSU Mataram berkisar antara 1-2 kali selama pasien dirawat. Tahapan konsultasi minimal frekuensi kunjungan menurut Departemen Kesehatan R.I. (1) adalah 2

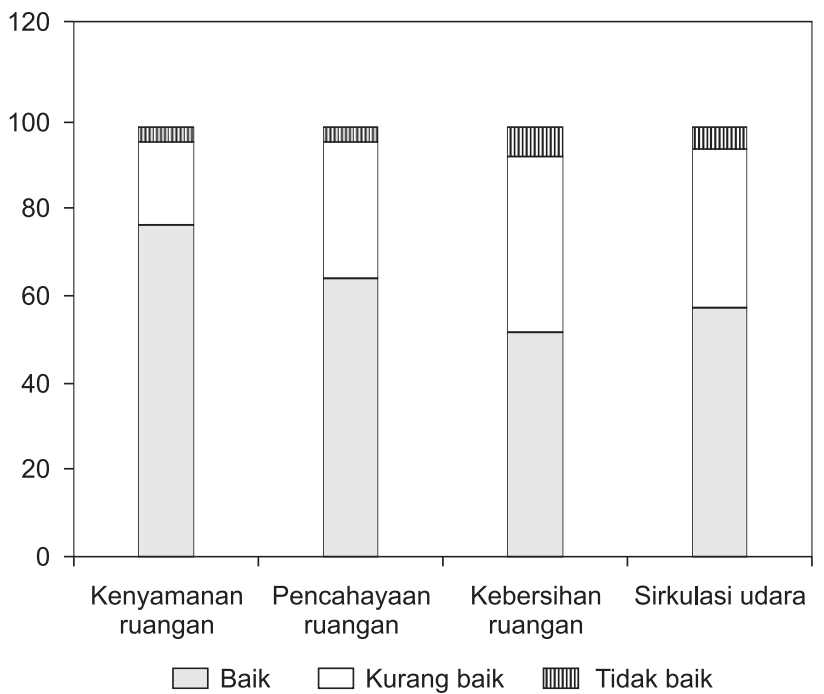

GAMBAR 5. Penilaian responden terhadap tempat konsultasi

kali, yaitu kunjungan untuk memberikan konsultasi gizi dasar dan konsultasi gizi lanjut. Tabel 4 menunjukkan bahwa 91,2\% responden mendapat konsultasi 1 kali dan $63,1 \%$ di antaranya menyatakan bahwa konsultasi sebanyak 1 kali dirasa cukup. Hal ini dapat disebabkan $82,5 \%$ responden adalah pasien yang baru pertama kali dirawat di RSU Mataram dan sebanyak $36,8 \%$ mendapat konsultasi pada hari kedua dirawat di RSU Mataram. Mengingat bahwa responden adalah pasien yang dirawat minimal 3 hari, frekuensi 1 kali kunjungan dinilai cukup. Hasil analisis Spearman rank correlation menunjukkan bahwa ada hubungan bermakna antara penilaian frekuensi konsultasi gizi dengan tingkat kepuasan responden terhadap pelaksanaan konsultasi gizi ruangan dengan korelasi positif dengan keeratan sedang $(p=0,000$ dan $r=0,452)$. Hasil ini menunjukkan bahwa makin banyak/sering kunjungan dilakukan, makin meningkat kepuasan pasien terhadap konsultasi gizi ruangan. Hal ini sesuai dengan pernyataan Yuniarti et al. (17) yang menyatakan bahwa tujuan konsultasi akan tercapai bila konsultasi dilakukan berulang untuk mengingat kembali materi yang telah disampaikan.

Faktor dominan pelayanan konsultasi yang berhubungan dengan tingkat kepuasan pasien rawat inap terhadap pelaksanaan konsultasi gizi

Tabel 5 menunjukkan hasil perhitungan uji regresi linear dan diketahui bahwa variabel frekuensi kunjungan merupakan faktor yang paling dominan di antara variabel

TABEL 4. Distribusi responden berdasarkan frekuensi kunjungan konselor

\begin{tabular}{lcccccc}
\hline Frekuensi & \multicolumn{2}{c}{ Cukup } & \multicolumn{2}{c}{ Kurang } & \multicolumn{2}{c}{ Jumlah } \\
\cline { 2 - 7 } konsultasi & $\mathbf{n}$ & $\mathbf{9}$ & $\mathbf{n}$ & $\mathbf{\%}$ & $\mathbf{n}$ & $\mathbf{\%}$ \\
\hline 2 kali & 5 & 8,8 & 0 & 0 & 5 & 8,8 \\
1 kali & 36 & 63,1 & 16 & 28,1 & 42 & 91,2 \\
Jumlah & $\mathbf{4 1}$ & $\mathbf{7 1 , 9}$ & $\mathbf{1 6}$ & $\mathbf{2 8 , 1}$ & $\mathbf{5 7}$ & $\mathbf{1 0 0 , 0}$ \\
\hline
\end{tabular}


TABEL 5. Hasil Uji regresi linier antara penilaian pelaksanaan konsultasi gizi ruangan dengan tingkat kepuasan responden terhadap pelaksanaan konsultasi gizi ruangan

\begin{tabular}{lccc}
\hline \multicolumn{1}{c}{ Variabel } & $\mathbf{R}$ & $\mathbf{R}^{2}$ & $\mathbf{p}$ \\
\hline Konselor & 0,293 & 0,086 & $0,027^{*}$ \\
Materi & 0,237 & 0,056 & 0,076 \\
Metode & 0,103 & 0,011 & 0,445 \\
Media & 0,242 & 0,059 & 0,070 \\
Waktu & 0,315 & 0,099 & $0,017^{*}$ \\
Tempat & 0,328 & 0,108 & $0,013^{*}$ \\
Frekuensi & 0,407 & 0,166 & $0,002^{*}$ \\
\hline
\end{tabular}

Keterangan:

* Bermakna $(p<0,05)$

TABEL 6. Hasil uji regresi linier berganda antara penilaian pelaksanaan konsultasi gizi ruangan dengan tingkat kepuasan responden terhadap pelaksanaan konsultasi gizi ruangan

\begin{tabular}{|c|c|c|c|c|}
\hline $\mathbf{R}$ & $\mathbf{R}^{2}$ & \multicolumn{2}{|c|}{ Koefisien regresi (B) } & p \\
\hline \multirow[t]{7}{*}{0,564} & 0,318 & Konselor & 0,110 & 0,434 \\
\hline & & Materi & 0,034 & 0,801 \\
\hline & & Metode & 0,085 & 0,501 \\
\hline & & Media & 0,135 & 0,333 \\
\hline & & Waktu & 0,121 & 0,379 \\
\hline & & Tempat & 0,246 & 0,051 \\
\hline & & Frekuensi & 0,287 & $0,035^{*}$ \\
\hline
\end{tabular}

Keterangan:

${ }^{*}$ Bermakna $(p<0,05)$

lain yang diteliti dengan nilai kuadrat koefisien regresi adalah 0,166 . Hal ini berarti persamaan garis regresi frekuensi kunjungan konselor dapat menerangkan $16,6 \%$ variasi tingkat kepuasan pasien terhadap pelaksanaan konsultasi gizi ruangan di RSU Mataram atau dapat dikatakan persamaan garis yang diperoleh kurang baik untuk menjelaskan variabel tingkat kepuasan pasien, demikian pula dengan variabel lain. Hal ini karena variabel lain memiliki nilai kuadrat koefisien regresi lebih rendah dari frekuensi kunjungan konselor, sehingga persamaan garis yang diperoleh rata-rata kurang baik untuk menjelaskan variabel tingkat kepuasan pasien.

Hasil uji pada Tabel 5 diperkuat dengan hasil uji linear berganda pada Tabel $\mathbf{6}$ yang menunjukkan bahwa konselor, materi, metode, media, waktu, tempat, dan frekuensi konsultasi hanya mempengaruhi tingkat kepuasan pasien sebesar 31,8\%; sedangkan faktor-faktor lain yang tidak diteliti mempengaruhi tingkat kepuasan pasien sebesar $68,2 \%$. Menurut Umarella (5), faktor-faktor lain yang dapat mempengaruhi tingkat kepuasan pasien terhadap pelaksanaan konsultasi ruangan adalah tingkat pendidikan dan pendapatan. Hal ini sesuai dengan hasil penelitian Fandani (9) di Sragen yang membuktikan bahwa makin tinggi tingkat pendidikan seseorang, makin rendah tingkat kepuasannya. Selain itu,

\section{RUJUKAN}

1. Departemen Kesehatan RI. Pedoman Praktis Terapi Gizi Medis. Jakarta: Direktorat Jenderal Bina Kesehatan Masyarakat Direktorat Gizi Masyarakat; 2006. dalam penelitian yang sama diketahui bahwa makin tua umur seseorang, makin rendah tingkat kepuasannya. Hal ini disebabkan makin tua umur seseorang, makin tinggi tuntutan untuk diperhatikan.

\section{KESIMPULAN DAN SARAN}

Berdasarkan hasil penelitian yang telah dilakukan di ruang rawat inap RSU Mataram dapat disimpulkan bahwa tidak ada hubungan yang bermakna antara konselor, materi, metode, dan media dengan tingkat kepuasan pasien rawat inap terhadap pelaksanaan konsultasi gizi ruangan. Sebaliknya, waktu, tempat, dan frekuensi konsultasi gizi didapatkan memiliki hubungan yang bermakna dengan tingkat kepuasan pasien rawat inap terhadap pelaksanaan konsultasi gizi ruangan. Faktor dominan yang mempengaruhi tingkat kepuasan pasien terhadap pelaksanaan konsultasi gizi ruangan adalah frekuensi konsultasi gizi.

Sehubungan dengan hasil penelitian tersebut, disarankan kepada konselor untuk melakukan pertemuan rutin mingguan untuk menyamakan persepsi. Selain itu, pihak manajemen gizi sebaiknya membuat kebijakan mengenai SOP pemberian materi konsultasi gizi dan pihak menajemen rumah sakit sebaiknya memberikan gordin/tirai pada kelas perawatan III agar privacy pasien dapat dijaga.

2. Iwaningsih S. Pengawasan dan Pengendalian Mutu dalam Pelayanan Gizi di Rumah Sakit. Prosiding Dewan Pimpinan Pusat Persatuan Ahli Gizi Indonesia (PERSAGI): 2005; Bali, Indonesia. 
3. Departemen Kesehatan RI. Buku Pedoman Pengelolaan Pelayanan Gizi Rumah Sakit. Jakarta: Direktorat Jenderal Pelayanan Medik Direktorat Rumah Sakit Khusus dan Swasta; 1991.

4. Lemeshow S, Hosmer D, Klar J. 1990. Adequacy of Sample Size in Health Studies. (Terjemahan) Pramono D. Yogyakarta: UGM Press; 1997.

5. Umarella R. Kepuasan Pasien Rawat Inap terhadap Pelayanan Gizi di Puskesmas Perawatan Pusat Gugus Kairatu Kabupaten Maluku Tengah [tesis]. Yogyakarta: Universitas Gadjah Mada; 1998.

6. Asih YY. Tingkat Kepuasan Pasien Rawat Jalan terhadap Pelaksanaan Konsultasi Gizi dan Faktorfaktor yang Mempengaruhi di Poliklinik Gizi RSUP dr. Sardjito Yogyakarta tahun 2003. Karya Tulis IImiah. Yogyakarta: Universitas Gadjah Mada; 2003.

7. Lamri LS. Pengaruh Kualitas Pelayanan terhadap Kepuasan, Minat, Perilaku Penderita Rawat Inap di Rumah Sakit Islam Samarinda. Jurnal Manajemen Pelayanan Kesehatan 1998; 01(01): 35-42.

8. Latipun. Psikologi Konseling. Malang: Universitas Muhammadiyah Malang; 2001.

9. Fandani F. Hubungan antara Persepsi Mutu Pelayanan dengan Kepuasan Pasien Rawat Jalan Umum Puskesmas Karangmalang Kabupaten Sragen [tesis]. Semarang: Universitas Diponegoro; 2004.
10. Departemen Kesehatan dan Kesejahteraan Sosial RI. Pedoman Konseling Gizi (Buku Modul Akademi Gizi). Jakarta: Direktorat Jenderal Kesehatan Masyarakat Direktorat Gizi Masyarakat; 2000.

11. Mulyati T, Prawirohartono EP, Sudargo T. Pengaruh Pendidikan Gizi kepada Ibu terhadap Konsumsi Makanan dan Status Gizi Anak Balita Penderita Tuberkulosis Primer di rAwat Jalan RSUP Dr. Kariadi Semarang. Jurnal Gizi Klinik Indonesia 2004; 1(2): 97-101.

12. Curry and Jaffe. Nutrition Counselling and Communication Skills. Washington: WB Saunders Company; 1998.

13. Ngadiarti. Upaya dalam Meningkatkan Keterampilan Pelayanan Gizi pada Penyuluh dan Konsultasi Gizi. Media Dietetik Assosiasi Dietesien Indonesia 2002; Jakarta.

14. Iswidani S. Pengembangan Daftar Tilik Konsultasi Gizi untuk Pasien DM di RSU Mataram, RS Syaiful Anwar Malang dan RS Sardjito Yogyakarta. Laporan Risbinakes. Mataram: Akademi Gizi Mataram; 2000.

15. Gable J. Counseling Skills for Dietttians. London: Blackwell Science; 1997.

16. Suryawati C. Penyusunan Indikator Kepuasan Pasien Rawat Inap Rumah Sakit di Propinsi Jawa Tengah. Jurnal Manajemen Pelayanan Kesehatan 2006; 09(04): 1-13.

17. Yuniarti $H$, Boediman D, Sudargo T. Pengaruh Konseling Gizi terhadap Status Gizi Ibu Hamil KEK pada Program JPS-BK di Kota Palembang. Jurnal Gizi Klinik Indonesia 2005; 01(03): 103-7. 